GEFAD / GUJGEF41(2): 797-816(2021)

\title{
The Effect of Open and Confirmatory Questioning Based Learning Approaches on the Success of Prospective Teachers on Geometric Optics Subjects*
}

\section{Açık ve Doğrulayıcı Sorgulamaya Dayalı Öğrenme Yaklaşımlarının Öğretmen Adaylarının Geometrik Optik Konularındaki Başarılarına Etkisi}

\author{
İbrahim YÜKSEL ${ }^{1}$, Merve EKER ${ }^{2}$, Ayşe Nesibe ÖNDER ${ }^{3}$, Ezgi GÜVEN YILDIRIM ${ }^{4}$ \\ ${ }^{1}$ Gazi Üniversitesi, Gazi Eğitim Fakültesi, Matematik ve Fen Bilimleri Eğitimi Bölümü, \\ Fen Bilgisi Eğitimi Anabilim Dal.ibrahimyuksel@gazi.edu.tr \\ ${ }^{2}$ Gazi Üniversitesi, Gazi Eğitim Fakültesi, Matematik ve Fen Bilimleri Eğitimi Bölümü, \\ Fen Bilgisi Eğitimi Anabilim Dalı.merveker1@gmail.com \\ ${ }^{3}$ Gazi Üniversitesi, Gazi Eğitim Fakültesi, Matematik ve Fen Bilimleri Eğitimi Bölümü, \\ Fen Bilgisi Eğitimi Anabilim Dalı.nkoklukaya@gazi.edu.tr \\ ${ }^{4}$ Gazi Üniversitesi, Gazi Eğitim Fakültesi, Matematik ve Fen Bilimleri Eğitimi Bölümü, \\ Fen Bilgisi Eğitimi Anabilim Dalı.ezgiguven@gazi.edu.tr
}

Makalenin Geliş Tarihi: 15.10.2019

Yayına Kabul Tarihi: 16.04.2021

\begin{abstract}
The aim of this study is to examine the effects of the applications in the General Physics Laboratory III (Geometric Optics Subjects) course on the academic achievement of prospective science teachers according to open questioning and confirmatory questioning learning approaches. In this context, a total of 44 pre-service teachers, 23 of whom were experimental and 21 of whom were in the control group, taking General Physics Laboratory III course in the second year of Science Education Program in a public university in Ankara in the 2018-2019 academic year fall semester form the study group of the research. The research was conducted within the framework of quasi-experimental design from quantitative research patterns. The data were collected as pre-test before the application process started and as post-test after the application process finished. SPSS 21 statistical analysis program was used to analyze the data. Descriptive statistical techniques were used to determine the general distributions of prospective teachers' responses to the test used in the study. The quasi-experimental design with pre-test and post-test control group in which the effects of laboratory practices organized according to open
\end{abstract}

\footnotetext{
* Alıntılama: Yüksel, İ., Eker, M., Önder, A. N. ve Güven-Yıldırım, E. (2021). The effect of open and confirmatory questioning based learning approaches on the success of prospective teachers on geometric optics subjects. Gazi Üniversitesi Gazi Eğitim Fakültesi Dergisi, 41(2), 797-816.
} 
questioning and confirmatory questioning-based learning approaches on the academic achievement of the prospective teachers were used. In the study, then, the achievement test posttest mean scores of the prospective teachers in the experimental and control groups were compared and a significant difference was found between the achievement test post-test mean scores in favor of the experimental group.

Keywords: Open questioning, Confirmatory questioning, Geometric optics, Academic achievement

$\ddot{O} Z$

$\mathrm{Bu}$ araştırmanın amacı açık sorgulamaya ve doğrulayıcı sorgulamaya dayalı öğrenme yaklaşımlarına göre düzenlenen Genel Fizik Laboratuvarı III (Geometrik Optik Konuları) dersindeki uygulamaların Fen Bilgisi ögrretmen adaylarının akademik başarılarına etkisinin incelenmesidir. Bu kapsamda araştırmanın çalışma grubunu, 2018-2019 ĕgitim-öğretim yılı güz döneminde Ankara ilinde bir devlet üniversitesinin Fen Bilgisi Öğretmenliği Programı ikinci sinıfinda okuyan, "Genel Fizik Laboratuvarı III" dersini alan 23'ü deney ve 21 'i kontrol grubu olmak üzere toplam 44 öğretmen adayı oluşturmaktadır. Araştırma nicel araştırma desenlerinden yarı deneysel desen çerçevesinde yürütülmüşü̈r. Veriler, uygulama süreci başlamadan önce ön test ve uygulama bittikten sonra son test olarak toplanmıştır. Verilerin analizinde SPSS 21 istatistik analiz programı kullanılmıştır. Öğretmen adaylarının çalışmada kullanılan teste verdikleri yanıtların genel dă̆llımlarının belirlenmesinde betimsel istatistik tekniklerinden yararlanılmıştır. Açık sorgulamaya ve doğrulayıcı sorgulamaya dayalı öğrenme yaklaşımlarına göre düzenlenen laboratuvar uygulamalarının ögretmen adaylarının akademik başarllarına etkisinin incelendiği ön test- son test kontrol gruplu yarı deneysel desen kullanılmıştır. Çalışmada deney ve kontrol grubunda yer alan öğretmen adaylarının başarı testi son test puan ortalamaları karşılaş̧ırılmış ve başarı testi son test puan ortalamaları arasında deney grubu lehine anlamlı bir fark bulunmuştur.

Anahtar Sözcükler: Açık sorgulama, Doğrulayıcı sorgulama, Geometrik optik, Akademik başarı

\section{INTRODUCTION}

According to the constructivist theory which lays a foundation for the new science education curricula, students are the learners who decide on their personal goals and approaches being responsible for their own learning, who establish connections between prospective learning outcomes, who question and discuss the results on their own. (Yapic1, 2011). Students has the role of researching the source of information, questioning, explaining, discussing and producing. (MEB, 2017). Questioning-based instruction (IQI) is a learning approach which emerged in the light of constructivist theory. IQI is seen as the most powerful approach that serves the learning process of 
students. (Lim, 2001). It has also been stated that the 2013 science education curriculum is based on IQI. Even though an eclectic approach has been embraced in the sense of learning theories and applications, in the curriculum, IQI approach is dominant, where generally students take responsible of their own learning, active participation is assured and learners build their own understanding. Likewise, 2017 science education curriculum is based on IQI approach. In the curriculum, it is indicated that a totalitarian approach exists in the sense of learning-teaching theories and a learning approach has been taken as a basis in which students are responsible of their own learning, actively participate and in which research-inquiry is evident along with information transfer. (MEB, 2017). IQI is not solely a step but a systematic whole of those steps that determines the purpose of the research process of each learner experiences as an example in everyday life. It is a systematic whole that learner detects variables, generates presuppositions about temporary outcomes or resolutions, i.e., generates hypothesis and tests these hypotheses while arriving at conclusions. (Lim, 2001). In the sense of what the students should do about it, IQI can be realized in 4 levels. (Kaya \& Y1lmaz, 2016). The first is the confirmatory questioning. At this level, the instructor provides the problem and data collection process openly. Students are not aware of the results during the activities. However, for them to reach the expected results, the activities that are going to used by the instructor are prepared in the format of a "cook book". The first level is relatively easier than the other 3 levels that the students confirm a principle with the activity of reaching the level, the results of which is known. The second level is the constructed questioning. At this level, the instructor provides the problem and the method to apply. Students find the results and interpret them. Students come to a solution by using this method for the problem. In contrast to the confirmatory questioning, the student does not know the solution that $\mathrm{s}$ he will come to but all the process is predetermined. In the third level, guided questioning, the students have been provided with some questions. Students also decide on how to test hypotheses. The student again tries to solve the problem provided to him or her but the method is not given. In the fourth and the last level which is the open questioning, nearly all the problem, primarily the hypothesis related research question, is constructed by the 
students. Conducting courses with the IQI approach contributes to the students by providing some insights about how scientific knowledge is obtained and what kind of process it goes through. It is known that having the courses with the IQI approach helps students to have success in science courses, to have a higher motivation towards the subject (Bilir, 2015; Demirkan, 2016). For an efficient IQI approach, the tenets should be applied fully by the instructors. In the literature, it is stated that, despite its evident benefits, instructors do not use IQI approach. Accordingly, the instructors lack a comprehensive understanding on IQI and believe that it is hard to apply (Huber \& Moore, 2001).

In the scope of General Physics Laboratory-III course, prospective science teachers should have knowledge to do experiments about geometric optics and should use appropriate approaches. Galili and Lavrik (1998) concluded that the reasons for the failure of the students in the teaching of geometric optics are due to the lack of teaching methods and materials. In addition, studies on the development of the IQI approach in the teaching of geometric optics subjects in our country have not been observed so much. In this study, in accordance with the constructivist learning theory, topics such as open questioning-based and confirmatory questioning-based learning approaches were organized for the teaching of geometric optical subjects within the scope of General Physics Laboratory-III course. The aim of this study is to examine the effects of the applications in the General Physics Laboratory-III (Geometric Optics Subjects) course on the academic achievement of prospective science teachers according to open questioning-based and confirmatory questioning-based learning approaches. In scope of this research, the sub-problems of the research are as follows:

1. Is there a significant difference between the pre-test and post-test mean scores of the prospective teachers in the experimental group?

2. Is there a significant difference between the achievement test pre-test and post-test mean scores of the prospective teachers in the control group?

3. Is there a significant difference between the achievement test pre-test mean scores of the prospective teachers in the experimental group and the control group? 
4. Is there a significant difference between the achievement test post-test mean scores of the prospective teachers in the experimental group and the control group?

\section{METHOD}

The research was conducted within the framework of quasi-experimental design from quantitative research patterns. Quasi-experimental design is one of the experimental methods that is to understand the cause and effect relation between variables (Fraenkel \& Wallen, 2005). In many educational researches, when all the variables cannot be taken under control, this method is preferred (Cohen, Manion \& Marrison, 2007). The quasi-experimental design with pre-test and post-test control group in which the effects of laboratory practices organized according to open questioning and confirmatory questioning-based learning approaches on the academic achievement of the prospective teachers were used (Büyüköztürk, 2008; Erdoğan, 2003). Research design of the study is given in Table 1 .

Table 1. Research Design

\begin{tabular}{llll}
\hline Groups & Pre-tests & Application & Post-tests \\
\hline Experiment & - Optic & Open questioning-based & - Optic \\
Group & Achievement Test & laboratory & Achievement Test \\
\hline $\begin{array}{l}\text { Control } \\
\text { Group }\end{array}$ & - Optic & $\begin{array}{l}\text { Confirmatory } \\
\text { questioning-based } \\
\text { laboratory }\end{array}$ & $\begin{array}{l}\text { - Optic } \\
\text { Achievement Test }\end{array}$ \\
\hline
\end{tabular}

\section{Study Group}

Participants are selected with purposive sampling which enables the researcher to choose the people who have the answers for the research questions. (Patton, 2002; Cohen, Manion \& Morrison, 2007). A total of 44 prospective teachers, 23 of whom were experimental and 21 of whom were in the control group, taking General Physics Laboratory-III course in the second year of Science Education Program in a public university in Ankara in the 2018-2019 academic year fall semester form the study group of the research 


\section{Data Collection Tool}

The Optical Achievement Test (OAT) was used as data collection tool in the research. Developed by Y1ldiz (2012), OAT consists of 19 questions including reflection of light, image features on the plane mirrors, special rays and images features in spherical mirrors, special rays and images features in lenses, breaking of the light and breaking laws, light and colors. 2 of these 19 questions are open-ended questions, 9 of them are drawing and explanation, and 8 of them are shape-meaning questions. The necessary corrections were made regarding the draft form of the test by referring to the opinions of 4 academic members who are experts in their fields. The questions were reorganized in a way that would be convenient to measure students' geometric optics knowledge at the basic level. Then, the reorganized test was validated by referring to the opinions of 4 faculty members who are experts in their field.

\section{Compliance with Ethical Rules}

Ethical principles and rules were followed at every stage of this research. Volunteer candidates participated in the data collection process of the current study. Participants were informed that the results of the study would only be used for the purpose of the study. The data obtained during the data collection process are given without any changes. References used in the research cited in accordance with scientific rules.

\section{Research Procedure}

In both groups, the OAT was applied as the pre-test in the first week before starting the application. Afterwards, the information about the approaches to be used in teaching geometric optics subjects were given to the prospective teachers in the groups. The application period lasted for 6 weeks, 2 lessons per week. The process was completed in 6 weeks by doing experiments in both groups with geometric optics laboratory subjects. At the last week, the achievement test was applied as a final test and the implementation process was ended in 8 weeks. In the control group, firstly, theoretical information was given to the teacher candidates about the experiments. Later, students made experiments with this information. But in the experimental group, theoretical information was not 
given to the students before the experiment and the teacher candidates did the experiments themselves.

\section{Data Analysis}

The data were collected as pre-test before the application process started and as post-test after the application process finished. SPSS 21 statistical analysis program was used to analyze the data. Descriptive statistical techniques were used to determine the general distributions of prospective teachers' responses to the test used in the study. Central tendency (mean and median) and central distribution (standard deviation, variance, skewness and kurtosis) values are recorded. Shapiro-Wilk test is conducted to see if the data show a normal distribution. According to the values shown in the Table 3, normal distribution is achieved ( $p>05$ ). Pre-test and post-test results of experiment and control groups are examined with dependent samples t-test. The effects of laboratory practices organized according to open questioning and confirmatory questioning-based learning approaches on the academic achievement of the prospective teachers are also examined by independent samples t-test. As a result of the independent sample test, the effect size $\left(\eta^{2}\right)$ was calculated in order to determine the size of the significant difference determined. According to Cohen (1988), the eta square value between .01 and .06 is interpreted as small, between .06 and .14 as medium, and between .14 and above as a large effect. Significance level is taken as .05 for all the test analysis used in this research.

\section{FINDINGS}

The data, before and after the implementation, is obtained from the achievement test that is applied to 44 teacher candidates, 23 of which is in experiment and 21 of which in control group. Firstly, the statistical procedure that is going to be applied to analyze the data coming from the results of the optical achievement test (OAT) is determined. In quantitative studies, if all the data coming from the tests show a normal distribution, parametric analysis techniques can be used (Çepni, 2007; Sim \& Wright, 2002). When 
the literature is examined, in the case of assuring 30 participants and over in the , normal distribution is accepted as existent according to central limit theorem (Gosling, 2004; Kwam \& Vidakovic, 2007). However, in this study, experiment group has 23 and control group has 21 teacher candidates. For this reason, to choose the appropriate statistical procedure, normal distribution has been checked. In order to ensure normality, descriptive statistics and Shapiro-Wilk test results has been provided in the tables (Table 2 and Table 3).

Table 2. Descriptive Statistics: Pre-test and Post-test Results of Experiment and Control Groups

\begin{tabular}{llccccccc}
\hline Tests & Group & $\mathrm{N}$ & $\overline{\mathrm{X}}$ & $\mathrm{SS}$ & Med. & Kur. & Skew. & Var. \\
\hline Pre-test & Experiment & 23 & 8.35 & 4.23 & 9 & -.15 & .07 & 17.87 \\
& Control & 21 & 6.52 & 3.28 & 6 & -.20 & .47 & 10.76 \\
Post-test & Experiment & 23 & 32.30 & 8.92 & 33 & .33 & .31 & 79.59 \\
& Control & 21 & 24.57 & 9.74 & 23 & .91 & .81 & 94.96 \\
\hline
\end{tabular}

Descriptive data related to groups' pre and post mean scores of optical achievement test has been shown in the Table 2. According to the data in the table, pre-achievement test mean score $(\bar{X}=8.35)$ of prospective teachers in the experimental group is close to the mean score $(\overline{\mathrm{X}}=6.52)$ of the prospective teachers in the control group and pre-test mean scores are low for each of the groups when the maximum score that is possible to get from the test is taken into consideration. When achievement post-test mean scores is examined, it has been seen that achievement test post-test mean scores $(\overline{\mathrm{X}}=32.30)$ of prospective teachers in the experimental group are higher from the achievement post test mean scores $(\overline{\mathrm{X}}=24.57)$ of prospective teachers in the control group.

Being examined the data in the table, it is found from the pre-measurements done before the application process and last measurements done after the process that achievement level of prospective teachers of each group has increased. Yet this rising is higher for the prospective teachers in the experimental group. When the table 2 is examined again, both experimental group and control group's mean score and median value related to achievement pre-test scores are close to each other. Similarly, experimental group and 
control group's mean scores and median value related to achievement post-test scores are almost equal to each other.

Closeness of mean scores and median values collected from all scales and tests is interpreted in the way that data are normally distributed (Köklü, Büyüköztürk \& Çokluk Bökeoğlu, 2006). When the kurtosis and skew values in the table 2 are examined, it is seen that these values are also between appropriate range (between -2 and +2 ) for a normal distribution (George \& Mallery, 2003). Shapiro-Wilk test results applied to the data without descriptive statistic are also presented in the Table 3.

Table 3. Shapiro-Wilk Test Results

\begin{tabular}{lccc}
\hline & Group & $\begin{array}{c}\text { Achievement pre- } \\
\text { test }\end{array}$ & $\begin{array}{c}\text { Achievement post } \\
\text { test }\end{array}$ \\
\hline Shapiro-Wilk (Sig) & Experimental & .58 & .94 \\
& Control & .50 & .10 \\
\hline
\end{tabular}

Being examined the data in the Table 3, scores of both experimental and control groups for the pre and post achievements tests are normally distributed ( $p>.05)$. Moving from this fact, it is decided that parametric tests are to be used in data analysis.

\section{Findings For The First Sub-Problem}

Dependent groups' t-test results concerning the study's first sub-problem that has been stated as "Is there a significant difference between the pre-test and post-test mean scores of the prospective teachers in the experimental group?" are shown in the Table 4.

Table 4. Dependent Groups' t-test Results Concerning Achievement Pre-test and Posttest Scores of Prospective Teachers in the Experimental Group

\begin{tabular}{lccccc}
\hline Group & $\mathrm{N}$ & $\overline{\mathrm{X}}$ & $\mathrm{SS}$ & $\mathrm{t}$ & $\mathrm{p}$ \\
\hline \multirow{2}{*}{ Experiment } & 23 & 8.35 & 4.23 & -10.62 & .00 \\
& 23 & 32.30 & 8.92 & \\
\hline
\end{tabular}

Pre and post test scores of prospective teachers in the experimental group have been examined through the dependent groups t-test and the results have been shown in the Table 4. While mean score of achievement pre-test for the prospective teachers in the experimental group is 8.35 , mean score of achievement post test is 32.30 . There is a 
significant difference between pre-test and post-test mean scores of the prospective teachers in the experimental group $(\mathrm{p}<.05, \mathrm{t}=-10.62)$.

\section{Findings For The Second Sub-Problem}

Dependent groups' t-test results concerning the study's second sub-problem that has been stated as "Is there a significant difference between pre-test and post-test mean scores of the prospective teachers in the control group?" are shown in the Table 5.

Table 5. Dependent Groups' t-test Results Concerning Achievement Pre-test and Posttest Scores of Prospective Teachers in the Control Group

\begin{tabular}{lccccc}
\hline Group & $\mathrm{N}$ & $\overline{\mathrm{X}}$ & $\mathrm{SS}$ & $\mathrm{t}$ & $\mathrm{p}$ \\
\hline \multirow{2}{*}{ Control } & 21 & 6.52 & 3.28 & -8.88 & \multirow{2}{*}{.00} \\
\hline
\end{tabular}

When the data in the Table 5 are examined, mean score of achievement pre-test for the prospective teachers in the control group is determined as 6.52 and mean score of achievement post-test is determined as 24.57. So there is a significant difference statistically between pre and post achievement test mean scores of prospective teachers in the control group $(\mathrm{p}<.05, \mathrm{t}=-8.88)$.

\section{Findings For The Third Sub-Problem}

Independent groups' t-test results concerning the study's third sub-problem that has been stated as "Is there a significant difference between the achievement pre-test mean scores of the prospective teachers in the experimental group and the control group?" are shown in the Table 6.

Table 6. Independent Groups' t-test Results Concerning Achievement Pre-test Scores of the Groups

\begin{tabular}{llcccl}
\hline Group & $\mathrm{N}$ & $\overline{\mathrm{X}}$ & $\mathrm{SS}$ & $\mathrm{t}$ & $\mathrm{p}$ \\
\hline Experiment & 23 & 8.35 & 4.23 & 1.59 & .12 \\
Control & 21 & 6.52 & 3.28 & & \\
\hline
\end{tabular}

When data in the Table 6 are examined, there has not been found a significant difference between pre-test mean scores, collected before the application, of prospective teachers in the experimental and control groups (experimental group $=8.35$; control 
group $=6.52$ ). The fact that there has not been a significant statistic difference between the mean scores of prospective teachers is appropriate in the context of analyzing the efficacy of applications.

\section{Findings For The Forth Sub-Problem}

Independent samples t-test results concerning the study' forth sub-problem are shown in the Table 7. The sub-problem has been stated as whether there is a significant difference between experimental group and control group prospective teachers' mean scores of post achievement test.

Table 7. Independent Groups t-test Results Concerning Groups' Achievement Post-Test Scores

\begin{tabular}{lcccccc}
\hline Group & $\mathrm{N}$ & $\overline{\mathrm{X}}$ & $\mathrm{SS}$ & $\mathrm{t}$ & $\mathrm{P}$ & $\eta^{2}$ \\
\hline Experiment & 23 & 32.30 & 8.92 & 2.75 & .00 & .15 \\
Control & 21 & 24.57 & 9.74 & 2.75 & \\
\hline
\end{tabular}

When the data in the table 7 are examined, it has been found out that achievement posttest mean score of prospective teachers in the experimental groups is $=32.30$ while achievement post-test mean score of prospective teachers in the control group is = 24.57. There is a statistical significant difference between achievement test scores, collected after the study, of prospective teachers in the experimental and control group $(\mathrm{p}<.05, \mathrm{t}=2.75)$. As a result of the tests, the effect size value in the study was calculated as $\eta^{2}=.15$ in favor of the experimental group. According to Cohen (1988), this value is interpreted as a large effect.

\section{RESULT and DISCUSSION}

Qualitative data have been collected through the use of achievement tests in this study in which the effect of open questioning-based and confirmatory questioning-based learning approaches, used in the education of General Physics Laboratory-III course, on the geometric achievement of prospective teachers is examined. Answers of participant prospective teachers has been analyzed via statistical analysis methods and following results are concluded according to the findings obtained. 
First of all, it is investigated in the study whether there is a significant difference between achievement pre-test mean scores of groups. It is seen that there has not been a significant difference between achievement pre-test mean scores of experimental group prospective teachers receiving education through open questioning-based learning approach and control group prospective teachers receiving education through confirmatory questioning-based learning approach. Afterwards, achievement post-test mean scores of prospective teachers in the experimental and control group are compared and a significant difference has been found between achievement post-test mean scores in favour of experimental group. Allowing prospective teachers in the experimental group to live the inquiry process with a student-centered way is thought as a reason for the significant difference. In line with the open-questioning based learning approach, prospective teachers have used both scientific process and critical thinking abilities effectively, worked on a problem using self-determined methods and solved the problem with processes containing their own research pattern; instead of constantly repeating and memorizing, which is done in the confirmatory questioning learning approach (Bell, Smetana \& Binns, 2005; Sadeh \& Zion, 2009; Zacharia, 2003). Reaching study results supporting the positive impact of open questioning-based learning approach on a student's success is possible when the literature is examined. For instance, the impact of open questioning-based learning on the academic success and scientific process abilities of the students was examined in the study conducted by Kaya and Yilmaz (2016). At the end of the study, it was concluded that open questioningbased learning was effective on development of students' academic success and scientific process abilities and questioning-based activities were suggested to be implemented in the science classes. In a study conducted in 2013, Karakuyu, Bilgin ve Sürücü studied the effect of questioning-based learning approaches on academic success and scientific abilities of prospective science teachers in General Physics Laboratory-I. At the end of the study, it was found out that success of General Physics Laboratory- I course of the students in the groups in which open-ended and guided study approaches were applied were higher than the success of the students in the groups in which constructivist and demonstrative were applied. In the studies of Tatar and Kuru (2006), 
questioning-based learning approach's impact on student's success, scientific process abilities and attitude towards science was examined. As a result of studies conducted experientially, it was concluded that questioning-based learning approach had a positive impact on all the variables. In the studies of Wallace, Tsoi, Calkin and Darley (2003), it was concluded that participant students preferred open-ended questioning-based learning instead of classes where traditional confirmatory type laboratory activities were used. As a result of the study, it was figured out that students understood the purpose of the experiment better through the use of this learning approach and they got more attention to laboratory studies. In another study conducted by Orcutt (1997), the impact of questioning-based science education on student success was researched. In this study including two experimental and two control groups; nature of the matter, acids and bases, ecological time units had been taught experimental groups via questioning-based teaching strategy for seven weeks and traditional teaching methods had been implemented in the control groups. At the end of the study, it was concluded that the success of experimental groups' students who had been taught via questioning-based learning approach was higher than the success of the students in control groups. As a result of an another study, it was found out that students, in a laboratory where open questioning-based approached was applied, were able to figure out variables affecting Newton's cooling experiment better and their academic success increased (Bartholow, 2007). Several domestic studies showed that questioning-based teaching approach increased students' success especially in science teaching (Akpullukçu, 2011; Babadoğan \& Gürkan, 2002; Çeliksöz, 2012; Erdoğan, 2005; Kaya, 2009; Sakar, 2010; Şen, 2010; Taşkoyan, 2008). In the studies of Göksu and Güneş (2019), they found that research inquiry-based laboratory method activities were more effective in increasing the success of science students in terms of force and motion than the activities prepared based on the confirmatory laboratory method. The reason for this was that the students in the experimental group were able to discuss the events in the laboratory during the activities, share them with their friends, and question the physical event, and they said that the student reached information more clearly. 
Moving from the findings coming out as a result of the study, it has been concluded that open questioning-based learning approach has a positive effect on the success of prospective teachers. When the results of the study are taken into consideration, in this context, it is suggested that different sample groups are included to the studies and the approach's effect on students' success in another lessons is examined. Nevertheless, researching the effect of open questioning-based learning approach on different variables through another studies is also possible. The use of student-centered alternative teaching approaches especially for applications implemented to primary and secondary school students and prospective teachers who are possible to become teacher of these students are considered to be important. 


\section{REFERENCES}

Akpullukçu, S. (2011). Fen ve teknoloji dersinde araştırmaya dayalı ögrenme ortamının ögrencilerin akademik başarı, hatırda tutma düzeyi ve tutumlarına etkisi. Dokuz Eylül Üniversitesi, İzmir.

Babadoğan, C., \& Gürkan, T. (2002). Sorgulayıcı öğretme stratejisinin akademik başarıya etkisi. Eğitim Bilimleri ve Uygulama, 1(2), 149-180.

Bartholow, M. (2007). A class inquiry into Newton's Cooling Curve. Journal of Chemical Education, 84(10), 1684-1685.

Bell, R. L., Smetana, L., \& Binns, I. (2005). Simplifying inquiry instruction. The Science Teacher, 72(7), 30-33.

Bilir, U. (2015). Fen Bilimleri öğretiminde araştırma ve sorgulamaya dayalı öğrenme sürecinin öğrencilerin akademik başarısına etkisi. Yayımlanmamış Yüksek Lisans Tezi. Uludağ Üniversitesi, Bursa.

Cohen, J. (1988). Statistical power analysis fort he behavioral sciences ( $\left.2^{\text {nd }} \mathrm{ed}.\right)$. Hillsdale, NJ: Erlbaum.

Cohen, L., Manion, L., \& Morrison, K. (2007). Research methods in education (6 ${ }^{\text {th }}$ ed.). New York: Routledge.

Çeliksöz, M. (2012). Farklı düzeylerdeki sorgulayıcı-araştırmaya dayalı ögrretim Yöntemlerinin ilköğretim öğrencilerinin başarı, tutum, bilimsel süreç becerisi ve bilgi kalıcllklarına etkileri. Yayınlanmamış Yüksek Lisans Tezi. Trakya Üniversitesi, Edirne.

Çepni, S. (2007). Araştırma ve proje çalışmalarına giriş. (3. basım). Trabzon: Celepler Matbaacilık.

Demirkıran, Z. A. (2016). Fen Bilimleri dersinde araştırma-sorgulamaya dayalı uygulamaların etkileri. Yayımlanmamış Yüksek Lisans Tezi. İstanbul Aydın Üniversitesi, İstanbul.

Erdoğan, İ. (2003). Pozitivist metodoloji, bilimsel araştırma tasarımı, istatistiksel yöntemler, analiz ve yorum, Ankara: ErkYayınevi.

Erdoğan, N. M. (2005). Illköğretim 7. sinıf öğrencilerinin atomun yapısı konusundaki başarılarına, kavramsal değişimlerine, bilimsel süreç becerilerine ve fene karşı tutumlarına sorgulayıcı- araştırma (inquiry) yönteminin etkisi. Yayınlanmamış Yüksek Lisans Tezi. Gazi Üniversitesi, Ankara.

Fraenkel, J. R., \& Wallen, N. E. (2005). How to design and evaluate research in education. ( ${ }^{\text {th }}$ ed). USA: New York: McGraw-Hill International Edition.

Galili, I., \& Lavrik, V. (1998). Flux Concept in learning about light: a critique of the present situation. Science Education, 82(5), 591-613.

George, D., \& Mallery, P. (2003). SPSS for Windows step by step: a simple guide and reference. Boston: Allyn\& Bacon. 
Gosling, J. (2004). Introductory statistics: a comprehensive, self-paced, step by step statistics course for tertiary students. Australia, Glebe: Pascal Press.

Goksu, V., \& Gunes, B. (2019). Araştırma Sorgulama ve Doğrulayıcı Laboratuvar Yöntemlerinin Fen Bilimleri Öğretmen Adaylarının Başarı, Kavram Yanılgısı ve Epistemolojik İnançları Üzerine Etkisi. Trakya Eğitim Dergisi, 9(3), 590611.

Hake, R. R. (1998). Interactive-engagement versus traditional methods: A six-thousandstudent survey of mechanics test data for introductory physics courses. American Journal of Physics, 66(1), 64.

Huber, R. A., \& Moore, C. J. (2001). A Model for extending hands-on science to be inquiry based. School Science and Mathematics, 101(1), 32-42.

Karakuyu, Y., Bilgin, İ., \& Sürücü, A. (2013). Araştırmaya dayalı öğrenme yaklaşımlarının üniversite öğrencilerinin Genel Fizik Laboratuvarı dersindeki başarı ve bilimsel süreç becerilerine etkisi. Mustafa Kemal Üniversitesi Sosyal Bilimler Enstitüsü Dergisi, 10(21), 237-250.

Kaya, B. (2009). Araştırma temelli öğretim ve bilimsel tartışma yönteminin ilköğretim öğrencilerinin asitler ve bazlar konusunu öğrenmesi üzerine etkilerinin karşılaştırılması. Yayınlanmamış Yüksek Lisans Tezi. Marmara Üniversitesi, İstanbul.

Kaya, G., \& Yılmaz, S. (2016). Açık sorgulamaya dayalı öğrenmenin öğrencilerin başarısına vebilimsel süreç becerilerinin gelişimine etkisi. Hacettepe Üniversitesi Ĕ̆itim Fakültesi Dergisi, 31(2), 300-318.

Köklü, N., Büyüköztürk, Ş. \& Çokluk, Bökeoğlu, Ö. (2006). Sosyal bilimler için istatistik. Ankara: Pegem A Yayıncılık.

Kwam, P. H., \& Vidakovic, B. (2007). Non parametric statistics with applications to science and engineering. New Jersey: A John Wiley\&Sons, Inc.

Lim, B. R. (2001). Guidelines for designing inquiry-based learning on the web: Online professional development of educators. PhD Thesis. Indiana University,USA.

MEB, (2013). İlköğretim kurumları Fen Bilimleri dersi ögretim programı. Ankara: MEB Yayınları.

MEB, (2017). Fen Bilimleri dersi ögretim programı (3, 4, 5, 6, 7 ve 8. Sinıflar). https://ttkb.meb.gov.tr/www/ogretim-programlari/icerik/72 adresinden alınmıştır.

Orcutt, C. B. J. (1997). A case study on inquiry-based science education and students' feelings of success. Unpublished Master Dissertation, San Jose State University, Washington.

Patton, M. Q. (2002). Qualitative research \& evaluation methods. (3 ${ }^{\text {rd }}$ ed). USA: Sage Publications. 
Sadeh, I., \& Zion, M. (2009). The development of dynamic inquiry performances within an open inquiry setting: Acomparison to guided inquiry setting. Journal of Research in Science Teaching, 46(10), 1137-1160.

Sakar, Ç. (2010). Araştırmaya dayalı kimya öğretiminin öğrencilerin akademik başarı ve tutumları üzerine etkisi. Yayınlanmamış Yüksek Lisans Tezi. Selçuk Üniversitesi, Konya.

Sim, J., \& Wright, C. (2002). Research in healthcare: concepts, design sand methods. United Kingdom, Cheltenham: Nelson Thornes Ltd.

Şen, H. C. (2010). Bir öğrenci özellikleri-uygulama etkileşimi çalışması: sorgulama temelli ögretim ve düz anlatım metotlarlyla ögretimin lise ögrencilerinin fizik başarısı üzerindeki etkisi. Yayınlanmamış Doktora Tezi. Orta Doğu Teknik Üniversitesi, Ankara.

Taşkoyan, S. N. (2008). Fen ve teknoloji öğretiminde sorgulayıcı öğrenme stratejilerinin, ögrencilerin sorgulayıc öğrenme becerileri, akademik başarı ve tutumları üzerindeki etkisi. Yayınlanmamış Yüksek Lisans Tezi. Dokuz Eylül Üniversitesi, İzmir.

Tatar, N., \& Kuru, M. (2006). Fen eğitiminde araştırmaya dayalı öğrenme yaklaşımının akademik başarıya etkisi. Hacettepe Üniversitesi Ĕ̈itim Fakültesi Dergisi, 31, 147-158.

Wallace, S. C., Tsoi, M. Y., Calkin, J., \& Darley, M. (2003). Learning from inquirybased laboratories in nonmajor biology: an interpretive study of the relationships among inquiry experience, epistemologies, and conceptual growth. Journal of Research in Science Teaching, 40(10), 986-1024.

Yapıcı, M. (2011). Yapılandırmacılık. (Ed. İ. Yıldırım), Eğitim psikolojisi. Ankara: Anı Yayıncilık.

Yıldız, M. (2012). Geometrik optik öğretiminde yapılandırmacı öğrenme kuramına dayalı olarak geliştirilen laboratuar materyallerinin etkililiğinin değerlendirilmesi. Yayımlanmamış Yüksek Lisans Tezi. Karadeniz Teknik Üniversitesi, Trabzon.

Zacharia, Z. (2003). Beliefs, attitudes and intentions of science teachers regarding the educational use of computer simulations and inquiry-based experiments in physics. Journal of Research in Science Teaching, 40(8), 792-823. 


\section{ORCID}

İbrahim YÜKSEL(D) https://orcid.org/0000-0001-5686-9344

Merve EKER $(D$ ttps://orcid.org/0000-0002-5938-7954

Ayşe Nesibe ÖNDER (D) https://orcid.org/0000-0001-7677-8861

Ezgi Güven YILDIRIM (D्D) https://orcid.org/0000-0002-8378-700X 


\title{
GENIŞ ÖZET
}

\begin{abstract}
Araştırmanın Amacı
Sorgulamaya Dayalı Öğrenme (SDÖ) yaklaşımıyla derslerin işlenmesi öğrencilerin bilimsel bilginin nasıl üretildiği ve bilim insanlarının hangi seviyelerden geçerek bu bilgileri ürettiğine ilişsin fikir sahibi olmalarına katkıda bulunur. SDÖ yaklaşımıyla derslerin işlenmesiyle ögrencilerin fen derslerinde başarılarının arttığı, bilimsel süreç becerilerinin ilerlediğ $i$, fene karşı tutum ve motivasyonlarının geliştiği bilinmektedir (Bilir, 2015; Demirkıran, 2016). Bu noktadan hareket ile bu araştırmanın amacı açık sorgulamaya dayalı öğrenme yaklaşımına ve doğrulayıcı sorgulamaya dayalı öğrenme yaklaşımlarına göre düzenlenen "Genel Fizik Laboratuvarı-III" dersindeki uygulamaların öğretmen adaylarının akademik başarılarına etkisinin incelenmesidir.
\end{abstract}

\section{Araştırmanın Yöntemi}

Açık sorgulama ve doğrulayıcı sorgulamaya dayalı ögrenme yaklaşımlarına göre düzenlenen laboratuvar uygulamalarının fen bilgisi öğretmen adaylarının akademik başarılarına etkisinin incelendiği bu araştırmada ön test- son test kontrol gruplu yarı deneysel desen kullanulmıştır (Erdoğan, 2003; Büyüköztürk, 2008). Katılımcılar, araştırmacının araştırma problemlerine cevap bulacağına inandiğ kişileri seçmesine olanak sağlayan amaçsal örnekleme ile belirlenmiştir (Patton, 2002; Cohen, Manion \& Morrison, 2007). Bu kapsamda araştırmanın çalışma grubunu, 2018-2019 eğitim-öğretim yıl güz döneminde Ankara ilinde bir devlet üniversitesinin Fen Bilgisi Öğretmenliği Programı ikinci sınıfinda okuyan ve "Genel Fizik Laboratuarı III" dersini alan 23 'ü deney, 21'i ise kontrol grubunda olmak üzere toplam 44 ögretmen adayl oluşturmaktadır. Araştırmada veri toplama aracı olarak Yıldı (2012) tarafindan gelişsirilen "Optik Başarı Testi" (OBT) kullanılmıştır. Uygulamaya başlamadan önce her iki grupta da ilk hafta optik başarı testi ön test olarak uygulanmıştır. Daha sonra gruplarda yer alan öğretmen adaylarına geometrik optik konularının öğretiminde kullanılacak yaklaşımlar hakkında bilgi verilmiştir. Uygulama süreci haftada iki ders saati olmak üzere toplam altı hafta sürmüştür. Altı hafta boyunca her iki grupta da geometrik optik laboratuvar konuları olan ışığın yansıması ve düzlem aynada görüntü, küresel aynalarda özel ışınlar ve görüntü, merceklerde özel ışınlar ve görüntü, ışığın kırılması ve kırılma kanunları, ışık ve renkler ile ilgili deneyler yapılarak süreç tamamlanmıştır. Son hafta ise başarı testi son test olarak uygulanarak uygulama süreci toplam sekiz haftada sonlandırılmıştır. Verilerin analizinde SPSS 21 analiz programı kullanılmıştır. Öğretmen adaylarının çalışmada kullanılan teste verdikleri cevapların genel dağllımlarının belirlenmesinde betimsel istatistik tekniklerinden yararlanılmıștır. Test puanlarına ait merkezi eğilim (ortalama ve medyan) ve merkezi dağılım (standart sapma, varyans, çarpıklık ve basıklı) değerleri kaydedilmiştir. Verilerin normal dağılım gösterip göstermediği Shapiro-Wilk testi ile incelenmiştir. Deney ve kontrol grubu öğretmen adaylarının grup içerisinde ön ve son test puan değiş̧imleri bağımlı gruplar t- testi ile incelenmiştir. Ayrıca açık sorgulamaya ve doğrulayıcı sorgulamaya dayalı ögrenme yaklaşımlarına göre düzenlenen laboratuvar ortamlarının ögretmen adaylarının akademik başarılarına etkisi bağımsız gruplar t-testi kullanılarak incelenmiştir. Araştırmada kullanılan bütün test analizlerinde anlamlılık düzeyi .05 olarak alınmıştır. 


\section{Araştırmanın Bulguları}

Araştırmada öncelikle grupların başarı testi ön test puan ortalamaları arasında anlamlı bir farklılık olup olmadığı araştırılmıştır. Açık sorgulamaya dayalı öğrenme yaklaşımı ile ögrenim gören deney grubu öğretmen adayları ile doğrulayıcı sorgulamaya dayalı öğrenme yaklaşımı ile ögrenim gören kontrol grubu öğretmen adaylarının başarı ön test puan ortalamaları arasında anlamlı düzeyde bir farklılık olmadiğı görülmüştür. Çalışmada daha sonra deney ve kontrol grubunda yer alan ögretmen adaylarının başarı testi son test puan ortalamaları karşılaştırılmış ve başarı testi son test puan ortalamaları arasında deney grubu lehine anlamlı bir farklilik bulunmuştur.

\section{Sonuç ve Öneriler}

Araştırma sonucunda ortaya çıkan bulgulardan hareketle, açık sorgulamaya dayalı öğrenme yaklaşımının ögretmen adaylarının başarısı üzerine olumlu yönde etkisi olduğu sonucuna varılmıştır. Bu durumun nedeninin uygulama süreci içerisinde deney grubunda yer alan ögretmen adaylarının tamamıyla öğrenci merkezli olarak sorgulama süreçlerini yaşamalarına firsat verilmesi olduğu düşünülmektedir. Bu kapsamda çalışmanın sonuçları göz önünde bulundurulduğunda, bu konuyla ilgili yapılacak diğer araştırmalarda yaklaşımın başka derslerde öğrenci başarısı üzerine etkisinin incelenmesi ve farklı örneklem gruplarının çalı̧̧malara dahil edilmesi önerilmektedir. Yine başka araştırmalar ile açı sorgulamaya dayalı öğrenme yaklaşımının farklı değişkenler üzerine olan etkisinin araştırılması mümkündür. Özellikle ilk ve ortaöğretim öğrencilerine ve ileride bu ögrencilere öğretmen olacak ögretmen adaylarına yönelik yapılan uygulamalarda öğrenci merkezli alternatif ögretim yaklaşımların kullanılmasının önemli olduğu düşünülmektedir. Genel Fizik Laboratuvart-III dersi konularının etkili bir şekilde ögretilebilmesi için derslerde somut ve soyut birçok kavramın yer aldı̆̆ etkinliklerde öğrenciler fiziksel olarak aktif olsalar da bilişsel olarak aktif olduklarından bahsedilemez. SDÖ'de ögrencilerin fiziksel olarak aktif olduklarl gibi bilişsel ola 